describe the ovaries. Fabricius certainly used the term "ovarium" for fowl and elasmobranch, and, equally, "testes" in the case of mammals; and Rolleston makes it clear, as the footnote does not, that the term "ova" was used by van Horne and de Graaf to describe the ovarian follicles. The word $\gamma \lambda \omega \chi^{i} \nu$ is given in Liddell and Scott not as "a strap", but as "a projecting point", or "the end of a yoke-strap", which makes sense when compared with the diagram on page 39 .

In my opinion, it is misleading to suggest (page 36) a close relationship between Galen's ideas about the effects of thoracic compression on pulmonary blood flow and the modern concept of the effects of the intrapleural negative pressure. The argument on page 157 is confusing in that the respiratory quotient is only unity if the volume of oxygen absorbed is equal to the $\mathrm{CO}_{2}$ output. So, too, on page 133, where to say that "the Galenic concept of filtration through pores was de facto demonstrated" (by electron-microscope studies) seems to me to contradict what has been put forward in the immediately preceding pages as being Galen's teaching. On page 180 we read "probably without knowledge of Galen's work, he" (that is, Boyle) "carried out his own experiment on respiration". The index to the 1772 edition of Boyle lists seventeen references to Galen, and I at least would be tempted to look for another reason for Boyle's omission of Galen's name here. I find it hard to accept (page 152) that Galen refuted all metaphysical ideas, or that he was not a vitalist within the usual meaning of the term, especially in view of the translations of Kühn, vol. 4, page 732, given on pages 144 and 171. Finally, statements such as "Modern neurophysiology will probably never be able to push its understanding beyond the limits which Galen so clearly defined" (page 186), and "Modern science has finally established the intricate hormonal and chemical mechanism by which normal and abnormal behaviour and even psychotic reactions can be explained" (page 241) seem to me both rash and contradictory. I regret having to criticize in matters of detail a book conceived to meet a very real need, and I look forward to seeing Siegel's promised volume on Galen's views on sense perception. D. W. TAYLOR

\section{SCIENCE OF THE PAST}

\section{A Short History of Science}

By J. G. Crowther. (Methuen General Studies Paperbacks.) Pp. 230. (Methuen Educational : London, January 1969.) $16 s$.

History of science and history of technology for the young should be written with as scrupulous care as for the mature, or even more so, for the young like to be told the truth, and are rightly suspicious of partially correct arguments. Young scientists and non-scientists alike can benefit and enjoy accurate discussions of science and technology in historical perspective which will show how these have developed at various periods and what the role of the individual, as an intellectual as well as a social being, has been. But they will rightly be put off by heroic myth, science as applied technology, and neat positivistic achievement.

This short book endeavours to compass all recorded history from the technology of ancient man to DNA and the space achievements of the 1960s; focused principally on the European tradition, it yet pays tribute to early Chinese science and technology. Further, Crowther attempts to pursue a plan of paying tribute to his heroes with anecdote and biography, and interspersing a certain amount of economic and social history; and all in twentyfive brief chapters. It is too much, and the result is often chaotic.

The theme is Crowther's view that science and tech- nology are inseparable, and, ignoring the modern historians' doubts about the historical truth of this in earlier ages, Crowther writes at length about those aspects of the science of the past that seem related to technology. Pure science, whether in the ancient world or in the more recent past, therefore fares badly. There are nearly five pages on Edison; there is no mention of Huygens, Euler, Laplace, Lamarck, Claude nor Bernard, to take a few names at random. The English tradition is stressed at the expense of the European: the foundation of the Royal Society appears here, but not that of the Académie Royale des Sciences; the 18th century observations of the Transits of Venus are described as a purely English effort to measure the solar system, and so on. Every writer must select; but Crowther has been excessively partial. So, too, while rightly rejecting Galileo and the Leaning Tower and Watt and the kettle, he yet retains other equally unfounded anecdotes without scruple. This is, disappointingly, not the standard of so professional a writer as Crowther; nor is the style, which is bald, flat and over simplified. The attempt to reach the young and ignorant by writing down is misjudged. This is not the book to inspire young people with an interest in science and technology; there are many better and less dated works available. There is no bibliography, though historians of science and technology are several times cited by name, with no explanation. The standard of production, especially of the well-chosen illustrations, is excellent. MARIE BoAs HaLL

\section{PLANT CLASSIFICATION}

\section{Modern Methods in Plant Taxonomy}

Edited by V. H. Heywood. (Botanical Society of the British Isles Conference Report, No. 10.) Pp. xv +312. (Academic Press: London and New York. Published for the Botanical Society of London, October 1968.) $84 s ; \$ 13.50$.

A QUick comparison of this book with Wilmott's British Flowering Plants and Modern Systematic Methods, published in 1949, immediately shows the great increase in the amount of information on which the plant taxonomist can now draw in producing his various classifications. While the latter deals almost exclusively with the use of cytological information as a taxonomic tool, the present work has a far wider coverage and considers, quite rightly, many more aspects of the plant.

This elegantly produced book, the contents of which are divided neatly into four parts, is based on papers presented at a very successful conference in 1967 organized jointly by the Botanical Society of the British Isles and the Linnean Society. Departing somewhat from tradition, speakers have presented their contributions in the form of reviews covering recently published work in their respective fields. Therefore, nothing in the way of new ideas or techniques appears for the first time. Limited space has inevitably meant that some topics have been omitted-pollen, for instance, has provided useful characters, and other microscopical features such as epidermal appendages and embryological data have enabled important contributions to be made in the taxonomy of many plant groups.

Introductory chapters explain quite rightly that herbaria have a continuing part to play in taxonomic practice today, whether as sources of operational taxonomic units for taximetric work, or as depositories for the all-important voucher specimens used in cytological or chemotaxonomic investigations. They can no longer be equated with mortuaries where dried botanical material can be left and forgotten. The succeeding chapters dealing with experimental data are stimulating and informative and are followed by others dealing with biochemistry and computers in taxonomy. Both of these 